REPORTS OF MORPHOLOGY
$\begin{gathered}\text { Official Journal of the Scientific Society of Anatomists, } \\ \text { Histologists, Embryologists and Topographic Anatomists } \\ \text { of Ukraine } \\ \text { journal homepage: https://morphology-journal.com }\end{gathered}$

\title{
Meibomian gland dysfunction and dry eye disease symptoms in patients with type 2 diabetes mellitus
}

\section{Zhmud T.M., Malachkova N.V., Andrushkova O.O., Hrizhymalska K.Y.}

National Pirogov Memorial Medical University, Vinnytsya, Ukraine

\section{ARTICLE INFO}

Received: 30 September, 2019

Accepted: 1 November, 2019

UDC: $617.77-002$

CORRESPONDING AUTHOR

e-mail: Gtatyana@email.ua Zhmud T.M.

\begin{abstract}
An important problem to date is the dysfunction of meibomian glands in patients with type 2 diabetes. The aim of our work was to analyze the prevalence of meibomian gland dysfunction and signs of dry eye disease in patients with type 2 diabetes. We examined 40 patients ( 80 eyes) with compensated type 2 diabetes mellitus and symptoms of dry eye disease, who made up the main group at the age of $54.00 \pm 8.00$ years, and 30 patients (60 eyes) of practically healthy people, aged $51.00 \pm 8.00$ years. All patients underwent visiometry, biomicroscopy, ophthalmoscopy, tonometry, compression test to evaluate the secretion of meibomian glands, Schirmer's test for compression before and after $30 \mathrm{~min}$. Afterwards, Norn test, meibography, Demodex mite test, laboratory tests (lipidogram, blood glucose, glycosylated hemoglobin). In addition, standard OSDI, McMonnies Dry Eye Questionnaire questionnaires were used and an average clipping rate of 1 min was determined. Statistical processing of the obtained results was carried out using the license package "Statistica 8.0" using parametric estimation methods. Our study has shown that in patients with diabetes for more than 5 years, dry eye disease occurs more often and is dominated by moderate and severe severity. Each patient in the study group, together with the symptoms of dry eye, had signs of dysfunction of the meibomian glands of varying degrees of severity according to the compression test and objective symptoms of the disease. A significant difference was found between the clipping frequency in the control group and the main one $(p \leq 0.01)$. Compared with the control group, patients with diabetes have a longer interval between the clipping movements. Meibography data show that patients in the primary group have changes in the meibomian glands in $90 \%$ of cases, while in the control group - $44 \%$. Thus, it was found that patients with type 2 diabetes had dysfunction of meibomian glands of moderate severity in $90 \%$ of cases, severe - in $10 \%$, which is associated with the duration of diabetes.
\end{abstract}

Keywords: diabetes mellitus, meibomian gland dysfunction, dry eye disease, meibography.

\section{Introduction}

Diabetes mellitus is a metabolic disorder that occurs with chronic hyperglycemia, insulin deficiency, insulin resistance and is accompanied by complications from the visual organ: development of retinopathy, cataracts, dry eye disease. According to the 2015 IDF Diabetes Atlas, about $91 \%$ of patients in high-income countries have type 2 diabetes. In 193 million cases, diabetes remains undiagnosed and causes a high risk of complications [16]. The manifestations of dry eye disease occur in $60-72 \%$ in patients with diabetes mellitus, while in the general population - 53\% [10]. The mechanism of dry eye disease in such patients has not yet been studied [8, 9], among the reasons are considered autoimmune dysfunction, reduction of corneal and conjunctival sensitivity as a result of neuropathy with the involvement of the lacrimal glands, increased osmolarity of the lacrimal function. A new understanding of this problem is reflected in the definition of dry eye syndrome: "Dry eye is a multifactorial disease of the ocular surface, characterized by the loss of homeostasis of the lacrimal film and accompanied by ocular symptoms in which instability of the lacrimal film and hyperosmolarity, inflammation and damage to the ocular surface and neurosensory abnormalities play an etiological role" [2, 12].

Many studies aimed at studying the pathogenesis of dry eye syndrome indicate that one of the important risk 
factors for dry eye disease is dysfunction of the meibomian glands [6, 21-23].

Dysfunction of the meibomian glands is one of the main causes of the development of posterior blepharitis [19] and dry eye disease [14]. Its frequency in the general population is $39-50 \%$ [13]. At blockage of openings of glands or stasis of lipids inside the gland, the secretion decreases and the composition of the lipid layer of the precorneal film changes, which normally stabilizes it and reduces evaporation [1, 16].

Chronic conditions such as cancer, diabetes and kidney failure are known to directly affect immunity. Skin infestations caused by Demodex sp. show progress in the case of humoral and cellular immune disorders. The formation of Demodex infection depends on internal factors such as sebaceous gland dysfunction and T-cell inhibition, as well as certain external factors. C. Gökçe et al. [4] found demodicosis in $24.6 \%$ of 69 patients with type 2 diabetes and concluded that impaired blood glucose regulation increased the sensitivity to $D$. Folliculorum infection. Some studies found a statistically significant $(p<0.001)$ difference in the determination of demodicosis in pregnant women with gestational diabetes (24.2\%) and without (3.3\%) [7].

The purpose of the study is to analyze the prevalence of dysfunction of the meibomian glands and the signs of dry eye disease in patients with type 2 diabetes.

\section{Materials and methods}

The main study group included 40 patients (80 eyes) with type 2 diabetes mellitus and symptoms of dry eye disease aged $54.00 \pm 8.00$ years, among them men - 18 $(45 \%)$, women - $22(55 \%)$. Duration of diabetes mellitus type 2 averaged 18 years. The main group was divided into two subgroups: №1 - with type 2 diabetes experience $<5$ years (34 eyes) and №2 - duration of diabetes $>5$ years (46 eyes). The control group consisted of 30 individuals (60 eyes) of healthy subjects, aged $51.00 \pm 8.00$ years.

The study followed the basic bioethical standards of the Helsinki Declaration of Human Rights and Biomedicine (1977), the requirements of the Helsinki Declaration of Human Rights (1975) and the Vancouver Convention (1979, 1994), relevant to the provisions of WHO, the International Council of Medical Scientific Societies, The International Code of Medical Ethics (1983) and the laws of Ukraine. All patients were informed and voluntary informed consent was obtained.

All patients underwent visiometry, biomicroscopy, ophthalmoscopy, tonometry, compression test to evaluate the secretion of meibomian glands, Schirmer's test for compression before and after $30 \mathrm{~min}$., Norn test, meibography, Demodex tick detection test, laboratory tests (lipidogram, blood sugar, glycosylated hemoglobin). In addition, standard OSDI, McMonnies Dry Eye Questionnaire questionnaires were used and an average clipping rate of 1 min was determined.

Meibography is a method of patient examination that allows to study in vivo the structure and morphological status of the meibomian glands. There are various techniques in the world, both contact and contactless screening. In our practice, we use a self-developed device based on photographing the turned eyelid in the infrared radiation spectrum (patent No. 127795 "Portable device for the study of the condition of the meibomian glands", patent No. 126656 "Method of obtaining images of the meibomian glands", 2018) [23]. This technique is non-invasive, noncontact, can be used with this device portably in all conditions and does not require prior preparation of the patient. The obtained data were estimated using the meibograde scale [20]. The method is based on three major changes in the meibomian glands: curvature, shortening and complete loss of glands [20]. The evaluation was performed on a 3-point scale: 0 - changes in the meibomian glands are absent, 1 there are changes in the meibomian glands at $33 \%$ of the eyelid area, 2 - impressions of the meibomian glands take up $33-66 \%$ of the eyelid area, 3 - more than $66 \%$ of the eyelid area have pathological changes in the meibomian glands.

Statistical processing of the obtained results was carried out using the license package "Statistica 8.0" using parametric estimation methods.

\section{Results}

All patients of subgroup № 1 had a decrease in the number of functioning glands by an average of $28.0 \%$ (according to the compression test) and revealed dysfunction of the meibomian glands of I-II severity. Dry eye disease of the mild degree in this subgroup was detected in $29.4 \%$ and the average degree in $47.0 \%$ of patients.

Patients of subgroup № 2 had a decrease in the number of functioning glands by an average of $48.2 \%$, grade III dysfunction of meibomian glands was observed in $28.2 \%$ (22 eyes); middle-grade dry eye disease was reported in $69.5 \%$, and three patients were diagnosed with a severe degree.

In the control group, the results of the compression test were normal.

The Demodex test was positive in $61.3 \%$ of the patients in the main group.

The main complaints that patients presented were: discomfort, tearing, heaviness of the eyelids, sensation of sand, redness, pain, itching. Moreover, most patients with type 2 diabetes had complaints of heaviness of the eyelids $(94.6 \%)$, discomfort in the eyes $(82.6 \%)$, redness that occurred periodically, more in the evening $(70.6 \%)$, sensation of sand and lacrimation ( $68.0 \%$ and $62.6 \%$ respectively).

The results of the Schirmer test before compression and after in subgroup № 1 were $5.910 \pm 0.100 \mathrm{~mm} / 5 \mathrm{~min}$. and $7.400 \pm 0.100 \mathrm{~mm} / 5 \mathrm{~min}$.; in subgroup № 2 - 4.910 \pm 0.100 $\mathrm{mm} / 5 \mathrm{~min}$. and $5.810 \pm 0.100 \mathrm{~mm} / 5 \mathrm{~min}$.; in the control group - $15.30 \pm 0.10 \mathrm{~mm} / 5 \mathrm{~min}$. and $17.70 \pm 0.10 \mathrm{~mm} / 5 \mathrm{~min}$., respectively $(p \leq 0.05)$.

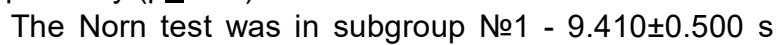
and in subgroup №2 - $8.150 \pm 0.500 \mathrm{~s}$; in the control group - 
$10.50 \pm 0.50 \mathrm{~s}(\mathrm{p} \leq 0.05)$.

The average clipping frequency was $14.00 \pm 0.80$ per min. in the main group and $29.00 \pm 1.00$ per min. in the control.

A significant difference was found between the clipping frequency in the control group and the main one $(p \leq 0.01)$. Compared with the control group, patients with type 2 diabetes have a longer interval between clipping movements.

Functional test scores correlate with duration of type 2 diabetes lasting $>5$ years $(\mathrm{r} 1=-0.68, \mathrm{r} 2=-0.56)$.

According to meibography data, patients in the main group showed changes in the meibomian glands in $90.0 \%$ of cases, while in the control group - in $44.0 \%$. According to indicators of the "meibograde" scale in patients of the main group amounted to $5.000 \pm 0.900$ points, which indicates the predominance of dysfunction of meibomian glands of moderate severity, and in those patients, who had diabetes for more than 5 years severe dysfunction of meibomian glands was detected in $14.0 \%$. In patients of the control group according to the indicators of the scale "meibograde" was $2.800 \pm 0.800$, which means that in patients of this group in $44.0 \%$ is dominated by dysfunction of meibomian glands of mild degree [22, 23].

According to lipidograms, $87.1 \%$ of patients with type 2 diabetes and dysfunction of the meibomian glands had a low level of high-density lipoproteins.

\section{Discussion}

In the studies of Figueroa-Ortiza L.C. et al. [3] found that dry eye disease in patients with diabetes is more often manifested on the basis of objective features than subjective ones. Their research has shown that most patients with dry eye disease have a decrease in goblet cell count. The higher prevalence of dry eye disease detected on the basis of examination and coloring data may also explain the presence of diabetic corneal neuropathy in patients with diabetes mellitus. An increased risk of infection in patients with diabetes [5] contributes to the combination of dry eye disease symptoms with chronic blepharitis in about $50 \%$ of patients. Such a course of diseases causes difficulties in establishing the primary link of pathogenesis and their etiology, causing difficulties for finding an effective treatment regimen [15].

Our study showed that in patients with type 2 diabetes for more than 5 years, dry eye disease occurs more often and is dominated by moderate and severe severity. The same pattern is observed in the study of the Nakonechnyi D.O. and Bezkorovaina I.M. [10]. M.R. Manaviat et al. [8] indicate that dry eye syndrome was present in $100 \%$ of patients with diabetes for 15 years or more. The results of FigueroaOrtiz L.C. et al. [3] among patients with diabetes without subjective symptoms of dry eye syndrome, according to

\section{References}

[1]Arita, R., Suehiro, J., Haraguchi, T., Shirakawa, R., Tokoro, H., \& Amano, S. (2014). Objective image analysis of the meibomian gland area. British Journal of Ophthalmology, 98(6), 746755. doi: 10.1136/bjophthalmol-2012-303014 the McMonnies questionnaire, found that $67.0 \%$ of the Schirmer test was normal, whereas in our study, almost every patient had signs of dry eye syndrome associated with prolonged suffering from diabetes mellitus and possibly lack of proper control over the course of the disease.

According to the DEWS classification, there are waterdeficient and water-vaporizing forms of dry eye disease, "dry eye" may be due to insufficient water component of the tear or increased evaporation of it [2]. Tear evaporation is a consequence of dysfunction of the meibomian glands [11, 18]. It is believed that the trigger of primary inflammation is dysfunction of the meibomian glands, which leads to pathological changes of the lacrimal film [15, 17].

Each patient in the study group, together with dry eye syndrome, had signs of dysfunction of the meibomian glands of varying degrees of severity according to the compression test and objective symptoms of the disease. A reliable relationship between the degree of dry eye syndrome and dysfunction of meibomian glands has been established in the studies by Tomlinson A. et al. [19] and Qiao J. and Yan X. [14], who believe that the main cause is the rapid evaporation of the aqueous layer of the lacrimal film due to lack of lipid. A study by Pathan R. [13] found that dysfunction of meibomian glands in patients with diabetes mellitus is a precursor to other eye diseases, including dry eye syndrome, and is found in $56.0 \%$, compared with the general population.

According to our previous studies [22], more than half of the patients had a Demodex test positive. In the study by G?k?e C. et al. [5] found that $24.6 \%$ (of 69 ) of patients with diabetes had a positive Demodex test regardless of age and gender. The authors suggest that inadequate blood glucose control increases the susceptibility to tick infection.

\section{Conclusions}

1. Metabolic disorders and dysfunction of the immune system in patients with type 2 diabetes contributes to the emergence of dysfunction of the meibomian glands and activation of conditionally pathogenic flora.

2. The degree of dry eye disease has been found to correlate with the duration of type 2 diabetes in patients suffering more than 5 years. Symptoms of a dry eye of moderate severity were observed 1.5 times more often in patients in whom type 2 diabetes lasted more than 5 years.

3. Changes in meibomian glands in patients with type 2 diabetes were found to be 2 times more frequent than in people of the same age without diabetes, and in patients with diabetes for more than 5 years there was mainly a dysfunction of meibomian glands and amounted to $90.0 \%$.

[2] Craig, J. P., Nelson, J. D., Azar, D. T., Belmonte, C., Bron, A. J., Chauhan, S. K., ... Nichols, J. J. (2017). TFOS DEWS II report executive summary. The Ocular Surface, 15(4), 802-812. doi: 10.1016/j.jtos.2017.08.003 
[3] Figueroa-Ortiz, L. C., Rodriguez, E. J., Garcia-Ben, A., \& GarciaCampos, J. (2011). Study of tear function and the conjunctival surface in diabetic patients. Archivos de la Sociedad Espanola de Oftalmologia (English Edition), 86(4), 107-112. doi: 10.1016/ s2173-5794(11)70020-2

[4] Gökçe, C., Aycan-Kaya, Ö., Yula, E., Üstün, I., Yengil, E., Sefil, F., ... Bayram, F. (2013). The effect of blood glucose regulation on the presence of opportunistic Demodex folliculorum mites in patients with type 2 diabetes mellitus. Journal of International Medical Research, 41(5), 1752-1758. doi: 10.1177/ 0300060513494730

[5] Gökçe, C., Aycan-Kaya, Ö., Yula, E., Üstün, I., Yengil, E., Sefil, F. ... Bayram, F. (2013). The effect of blood glucose regulation on the presence of opportunistic Demodex folliculorum mites in patients with type 2 diabetes mellitus. Journal of International Medical Research, 41(5), 1752-1758. doi: 10.1177/0300060513494730

[6] Kashnykova, O. A., Maichuk, D. Yu., \& Polunyn, G. S. (2004). Use of soft contact lenses in patients with symptomatic dry eyes. Refractive surgery, 4(1), 52-58.

[7] Kurt, R. K., Kaya, O. A., Karateke, A., Silfeler, D. B., Karapinar, O. S., Akkoca, A. N., \& Hakverdi, A. U. (2014). Increased density of Demodex folliculorum mites in pregnancies with gestational diabetes. Medical Principles and Practice, 23(4), 369-372. doi: 10.1159/000363244

[8] Manaviat, M. R., Rashidi, M., Afkhami-Ardekani, M., \& Shoja, M. R. (2008). Prevalence of dry eye syndrome and diabetic retinopathy in type 2 diabetic patients. BMC Ophthalmology, 8(1), 10. doi: 10.1186/1471-2415-8-10

[9] Najafi, L., Malek, M., Valojerdi, A. E., Khamseh, M. E., \&Aghaei, H. (2015). Dry eye disease in type 2 diabetes mellitus; comparison of the tear osmolarity test with other common diagnostic tests: a diagnostic accuracy study using STARD standard. Journal of Diabetes \& Metabolic Disorders, 14(1), 39. doi: 10.1186/s40200-015-0157-y

[10] Nakonechnyi, D. O., \& Bezkorovaina, I. M. (2015). Control of the course of the "dry eye" syndrome in patients with diabetes mellitus by the method of tear crystallography when using a combined preparation based on trehalose and hyaluronate sodium. Topical Problems of Modern Medicine: Bulletin of the Ukrainian Medical Dental Academy, 1, 5(4(52)), 194-199.

[11] Németh, J., Fodor, E., Lang, Z., Kosina-Hagyó, K., Berta, A., Komár, T. ... Kemer, O. E. (2012). Lid-parallel conjunctival folds (LIPCOF) and dry eye: a multicentre study. British journal of ophthalmology, 96(11), 1380-1385. doi: 10.1136/bjophthalmol2012-301580

[12] Nichols, K. K., Foulks, G. N., Bron, A. J., Glasgow, B. J., Dogru,
M., Tsubota, K. ... Sullivan, D. A. (2011). The international workshop on meibomian gland dysfunction: executive summary. Investigative Ophthalmology \& Visual Science, 52(4), 1922-1929. doi: https://doi.org/10.1167/iovs.10-6997a

[13] Pathan, R. (2015). Prevalence of meibomian gland disease in type II diabetic patients \& its clinical presentations. J. Evid. Based. Med., 2(4), 346-353. doi: 10.18410/jebmh/51

[14] Qiao, J., \& Yan, X. (2013). Emerging treatment options for meibomian gland dysfunction. Clinical ophthalmology (Auckland, NZ), 7, 1797-1803. doi: 10.2147/OPTH.S33182

[15] Rapuano, C. J. (2008). American Academy of Ophthalmology Cornea/External Disease Panel. Preferred Practice Pattern Guidelines. Conjunctivitis.

[16] Shamsheer, R. P., \& Arunachalam, C. (2015). Aclinical study of meibomian gland dysfunction in patients with diabetes. Middle East African Journal of Ophthalmology, 22(4), 462-466. doi: 10.4103/0974-9233.167827

[17] Stapleton, F., \& Carnt, N. (2012). Contact lens-related microbial keratitis: how have epidemiology and genetics helped us with pathogenesis and prophylaxis. Eye, 26(2),185-193. doi: 10.1038/eye.2011.288

[18] Sullivan, B. D., Evans, J. E., Krenzer, K. L., Reza Dana, M., \& Sullivan, D. A. (2000). Impact of antiandrogen treatment on the fatty acid profile of neutral lipids in human meibomian gland secretions. The Journal of Clinical Endocrinology \& Metabolism, 85(12), 4866-4873. doi: https://doi.org/10.1210/ jcem.85.12.7066

[19] Tomlinson, A., Bron, A. J., Korb, D. R., Amano, S., Paugh, J. R., Pearce, E. I., ... \& Dogru, M. (2011). The international workshop on meibomian gland dysfunction: report of the diagnosis subcommittee. Investigative ophthalmology \& visual science, 52(4), 2006-2049. doi: 10.1167/iovs.10-6997f

[20] Wise, R. J., Sobel, R. K., \& Allen, R. C. (2012). Meibography: A review of techniques and technologies. Saudi Journal of Ophthalmology, 26(4), 349-356. doi: 10.1016/ j.sjopt.2012.08.007

[21] Zabehailo, A. O., Safonova, T. N., \& Makarov, I. A. (2013). A new way to determine the severity of the blepharoconjunctival form of "dry eye" syndrome. Cataract and Refractive Surgery, 13(1), 35-38.

[22] Zhmud, T. M., \& Drozhzhina, G. I. (2019). Meibomian gland dysfunction accompanied by palpebral demodicosis in patients with type 2 diabetes mellitus. Journal of Ophthalmology, 6(491), 23-28. doi.org/10.31288/oftalmolzh201962328

[23] Zhmud, T. M., Nikolaichuk, D. V., \& Nikolaichuk, V. I. (2018). Improvement of the technique of non-contact portable meibography. Oftalmologiia. Eastern Europe., 8(4), 488-496.

\section{ДИСФУНКЦІЯ МЕЙБОМІЄВИХ ЗАЛОЗ ТА ОЗНАКИ СУХОГО ОКА У ХВОРИХ 3 ЦУКРОВИМ ДІАБЕТОМ 2 ТИПУ Жмудь Т.М., Малачкова Н.В., Андрушкова О.О., Гріжимальська К.Ю.}

Важливою проблемою на сьогоднішній день є дисфункція мейбомієвих залоз у хворих з цукровим діабетом 2 типу. Метою нашої роботи було проаналізувати поширеність дисфункції мейбомієвих залоз та ознак хвороби сухого ока у хворих 3 цукровим діабетом 2 типу. Було обстежено 40 пацієнтів (80 очей) з компенсованим цукровим діабетом 2 типу та симптомами

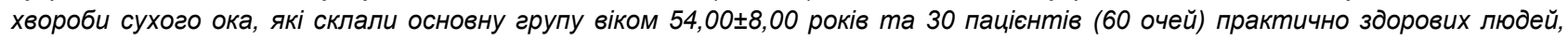

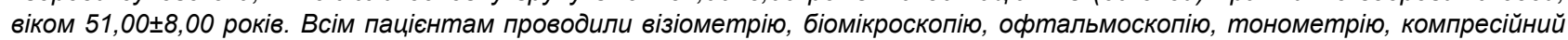
тест для оцінки секреції мейбомієвих залоз, пробу Ширмера до компресії та через 30 хвилин після неї, пробу Норна, мейбографрiю, mест на виявлення кліща Demodex, лабораторні дослідження (ліпідограма, глюкоза крові, глікозильований гемоглобін). Крім того, використовували стандартні опитувальники OSDI, McMonnies Dry Eye Questionnaire та визначали середню частоту кліпання за 1 хвилину. Статистична обробка отриманих результатів проведена за допомогою ліцензійного пакету "Statistica 8.0" з використанням параметричних методів оцінки. Проведене нами дослідження показало, що у пацієнтів з тривалістю иукрового діабету більше 5 років хвороба сухого ока виникає частіше та переважає середній та важкий ступінь тяжкості. За даними компресійного тесту та об'єктивними симптомами захворювання кожен пацієнт досліджуваної групи разом із симптомами сухого ока мав ознаки дисфрункції мейбомієвих залоз різного ступеня вираженості. Виявлена 
достовірна різниця між частотою кліпання у контрольній групі та у основній (p<0,01). У порівнянні з контрольною групою, хворі на иукровий діабет мають довший інтервал між кліпальними рухами. За даними мейбографії встановлено, що у пацієнтів основної групи зміни мейбомієвих залоз зустрічаються у 90\% випадків, тоді як в контрольній групі - у 44\%. Таким чином, встановлено, що у хворих з иукровим діабетом 2 типу виявлено дисфункцію мейбомієвих залоз середнього ступеня важкості у 90\% випадків, важкого ступеня - у 10\%, що пов'язано з тривалістю діабету.

Ключові слова: иукровий діабет, дисфункція мейбомієвих залоз, хвороба сухого ока, мейбографія.

\section{ДИСФУНКЦИЯ МЕЙБОМИЕВЫХ ЖЕЛЕЗ И ПРИЗНАКИ СУХОГО ГЛАЗА У БОЛЬНЫХ С САХАРНЫМ ДИАБЕТОМ 2 ТИПА Жмудь Т.М., Малачкова Н.В., Андрушкова О.А., Грижимальская Е.Ю.}

Важной проблемой сегодняшнего дня является дисфункция мейбомиевых желез у больных сахарным диабетом 2 типа. Целью нашей работы было проанализировать распространенность дисфунккции мейбомиевых желез и признаков болезни сухого глаза у больных с сахарным диабетом 2 типа. Было обследовано 40 пациентов (80 глаз) с компенсированным

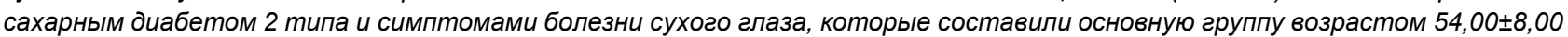

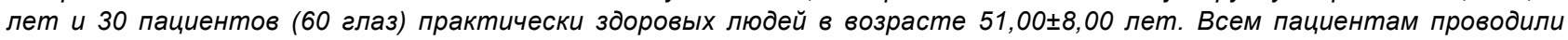
визиометрию, биомикроскопию, офртальмоскопию, тонометрию, компрессионный тест для оценки секреции мейбомиевых желез, пробу Ширмера перед компрессией и через 30 минут после нее, пробу Норна, мейбографию, тест на клеща Deтодех, лабораторные исследования (липидограмма, глюкоза крови, гликозилированный гемоглобин). Кроме того, использовали стандартные опросники OSDI, McMonnies Dry Eye Questionnaire и определяли среднюю частоту моргания за 1 мин. Cтатистическая обработка полученных результатов проведена с помощью лицензионного пакета "Statistica 8.0" c использованием параметрических методов оценки. Проведенное нами исследование показало, что у пациентов $c$ длительностью сахарного диабета более 5 лет болезнь сухого глаза возникает чаще и преобладают средние и тяжелые степени тяжести. По данным компрессионного теста и объективных симптомов заболевания каждый пациент исследуемой группы вместе с симптомами сухого глаза имел признаки дисфункции мейбомиевых желез различной степени выраженности. Выявлена достоверная разница между частотой моргания пациентов контрольной группы и основной $(p \leq 0,01)$. По сравнению с контрольной группой, больные сахарным диабетом имеют более длительный интервал между мигательными движениями. По данным мейбографии установлено, что у пациентов основной группы изменения в мейбомиевых железах встречаются в 90\% случаев, тогда как в контрольной группе - у 44\%. Таким образом, установлено, что у больных с сахарным диабетом 2 типа выявлена дисфункция мейбомиевых желез средней степени тяжести в 90\% случаев, тяжелой степени - в $10 \%$, что связано с длительностью диабета.

Ключевые слова: сахарный диабет, дисфункция мейбомиевых желез, болезнь сухого глаза, мейбография. 